\title{
Intelligent Control and Systems
}

DOI: https://doi.org/10.15407/kvt202.04.044

UDC $004.9+681.5$

ODARCHENKO R.S., DSc (Engineering), Associate professor, Leading Researcher of the Intelligent Control Department, e-mail: odarchenko.r.s@ukr.net

ORCID: 0000-0002-7130-1375

VOLKOV O.Ye.,

Head of the Intelligent Control Department

e-mail: alexvolk@ukr.net

ORCID: 0000-0002-5418-6723

SIMAKHIN V.M., PhD student,

Junior Researcher of the Intelligent Control Department e-mail: thevladsima@gmail.com

ORCID: 0000-0003-4497-0925

SEMENOG R.V., PhD student,

Junior Researcher of the Intelligent Control Department e-mail: ruslansemenog20@gmail.com

ORCID: 0000-0002-6714-0644

GOSPODARCHUK O.Yu.,

Senior Researcher of the Intelligent Control Department, e-mail: dep185@irtc.org.ua

ORCID: 0000-0001-6619-2277

International Research and Training Center

for Information Technology and Systems

of National Academy of Sciences of Ukraine

and Ministry of Education and Science of Ukraine,

40, Acad. Glushkov av., 03187, Kyiv, Ukraine

\section{TECHNOLOGY OF INTELLIGENT CONTROL OF UNMANNED AERIAL VEHICLES MONITORING III THE AIRSPACE USING $5 \mathrm{G}$ CELLULAR NETWORKS}

Introduction. The increasing number of unmanned aerial vehicles (UAVS) in the airspace, as well as the imperfection of the regulatory framework for the regulation of their activities, poses numerous challenges to regulators. This work proposes the development of intelligent technologies and soft-/hardware systems combined with state of the art $5 G$ cellular networks for solving problems of UAV registration and monitoring.

(c) ODARCHENKO R.S., VOLKOV O.Ye., SIMAKHIN V.M., GOSPODARCHUK O.Yu., 2020 
The purpose of the paper is to analyze the state of the UAV market and related legislation in the world and Ukraine; to develop the technology for intelligent control of UAV monitoring using cellular networks; to prepare guidelines for the implementation and application of the system.

Methods. The methods of data transmission in $5 G$ networks and construction of global distributed IoT networks for the implementation of monitoring technology, methods of data analysis and detection of anomalies for the study of events occurring in the UAV network were used.

Results. The technology of intelligent monitoring of UAVS with the use of a modern $5 G$ cellular network was developed. The use of the fifth generation network provides high data transfer speeds with ultra-low latency and meets all the necessary security requirements. The technology of intelligent control of UAV monitoring consists of separate methods, which are executed in the monitoring center, data processing center and in the supervisory control and data acquisition system. The use of cellular base stations for primary data processing and filtering speeds up the events processing in the UAV network.

Conclusions. The results of the work can be used by civil aviation regulators for monitoring the usage of airspace by unmanned aerial vehicles, as well as for prevention of casualties and emergencies.

Keywords: information technology, monitoring system, registration system, unmanned aerial vehicle, $5 G$ network.

\section{INTRODUCTION}

The total market value of unmanned aerial vehicles (UAVs) in the world is estimated at 19.3 billion US dollars and is expected to reach 45.8 billion by the year 2025. The markets of North America and Asia are the most developed and expensive (Fig. 1). Depending on the application, the UAV market is divided into military, commercial, government, law enforcement and consumer segments. Currently, the military market is the most technologically advanced the largest in terms of sales, but the least accessible for the consumers. According to forecasts, the commercial market segment will grow at the maximum average annual rate. This can be explained by the expansion of the range of UAVs application for various commercial purposes, such as product delivery, monitoring, land surveying, cartography and remote sensing.

\section{UAV MARKET, BY REGION (USD BILLION)}

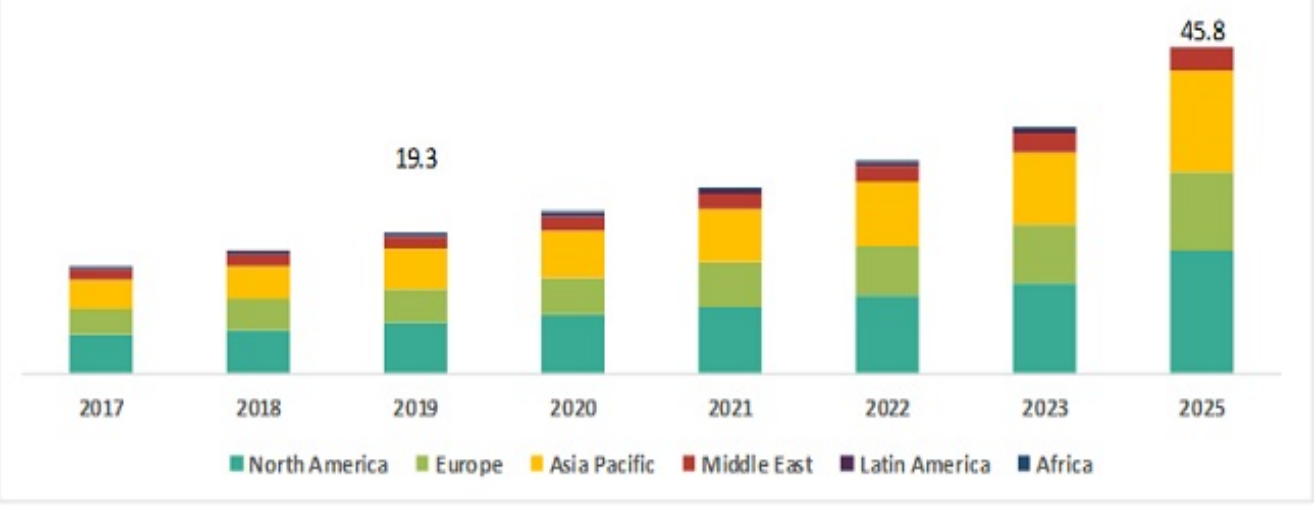

Fig. 1. UAV market by macro-regions of the world [1] 
Ukraine ranks 27 th in the world by the variety of UAV models, but domestic production is only $7 \%$ of the total quantity. At the same time, almost $90 \%$ of all UAVs are purchased in China, the United States and Israel. Today, the undisputed market leader is the Chinese company DJI, which owns more than $70 \%$ of the global consumer market and more than $80 \%$ of the Ukrainian market [2].

UAV safety is one of the most important tasks that require reliable solutions, given the active use of UAVs in business and in everyday life. The introduction of advanced information technologies into the industry plays a significant role in its development. According to the Strategic Plan for the Development of Air Transport in Ukraine, the priorities include ensuring the safe operation of UAVs, as well as the implementation and supervision of compliance with the Aviation Rules of Ukraine for the operation of UAVs. One of the components of supervision is the registration and storage of information about the owner, place and date of purchase, the serial number of the device etc.

An increase in the number of UAVs of different types in the airspace will inevitably lead to its overflow. It is necessary to apply fundamentally new approaches to UAV monitoring to prevent accidents that could lead to aircraft crashes and further casualties. One of the possible options is constant tracking of UAV movements in the air, though an important disadvantage of this approach is the significant energy costs for constant determination and transmission of coordinates. A promising way to solve this shortcoming is the use of $5 \mathrm{G}$ cellular networks, the functional features of which are suitable for use in UAVs.

\section{FORMULATION OF THE PROBLEM AND RESEARCH OBJECTIVES}

The airspace of Ukraine is defined and established by the standards of the international organization ICAO, the documents of the international organization Eurocontrol, the Regulations on the Usage of Airspace of Ukraine and the Air code of Ukraine [3]. Permission and conditions for the use of airspace are issued by the bodies of the joint civil-military system of air traffic control based on an application for the use of airspace, excluding cases as provided by the Air Code of Ukraine.

UAVs present a wide range of hazards for the civil aviation system [4] and these hazards must be identified and eliminated [5]. All ICAO member countries must comply with the relevant laws authorizing the usage of European airspace and establishing the conditions for its use by the civil-military air traffic control system based on applications for the use of airspace. According to the ICAO Chicago Convention [6], all UAVs, regardless of whether they are remotely manned, fully autonomous or mixed, are subjected to the provision of Article 8, which concerns obtaining a special service release. According to Article 31, each UAV must have an airworthiness certificate.

Among the various favorable technologies for the registration and monitoring of UAVs, wireless communication is important and has attracted considerable attention in recent years [7]. Indeed, many studies around the world are now exploring the possibilities for servicing commercial UAVs with cellular networks. Manufacturers of cellular networks are testing prototypes of unmanned base stations (UBSs), while research institutions are studying and developing mathematical and algorithmic solutions to solve new problems that arise with the development of UBSs. In [8] similar developments and their influence on the integration of UAVs into the cellular network 
are analyzed. Proceedings [9-11] are devoted to the analysis of wireless technologies, new opportunities and challenges of these technologies when using communications with UAVs; in [12-13] the improvement of the fourth-generation cellular networks (LTE) was carried out to increase the efficiency of UAV operation; in [14] an overview of unresolved problems in UAV communications is carried out.

To optimize existing and build new wireless remote registration and UAV monitoring systems with $4 \mathrm{G}$ and $5 \mathrm{G}$ cellular networks, it is necessary to develop methods that will improve the performance of cellular communication networks so that they can meet the necessary criteria in urban conditions. It is also necessary to ensure the introduction of new and support for existing mobile systems that should meet the requirements of modern network architecture, create effective traffic management tools and ensure a sustainable service quality indicator.

Communication is one of the key issues in creating a UAV monitoring system. The fastest possible transmission of information with minimal delay and high reliability of data delivery are required. That is why universal coverage of modern cellular networks should be carried out in Ukraine to properly support radio access technologies. Under these conditions, 5G cellular communication technologies can significantly improve the quality of the main criteria required for UAV monitoring.

The purpose of the paper is to analyze the state of the UAV market and related legislation in the world and Ukraine; to develop the technology for intelligent control of UAV monitoring using cellular networks; to prepare guidelines for the implementation and application of the system.

\section{UAV MONITORING SYSTEM ARCHITECTURE}

The monitoring of objects is usually defined as the systematic accumulation and processing of information about the state and dynamics of changes in the parameters of the analyzed object or process, and the presentation of results in a form convenient for the supervisor. Monitoring systems combine hardware and software, and wired or wireless data transmission technologies are used for their interaction. Observing dynamic objects, such as UAVs, is quite a challenge, especially outside densely populated areas, as the transmission of information about the condition and location of the aircraft can be difficult. With the provision of sufficient coverage of the territory by cellular networks of the fourth and higher generations, the problem of data transmission is minimized.

In general, the monitoring system using cellular networks consists of a monitoring center, supervisory control and data acquisition system (SCADA), base stations (BS) of cellular networks and UAV networks (Fig. 2). The main monitoring center contains a separate data processing center (DC), which receives information, and means for presenting information to monitoring operators. SCADA performs data acquisition and analysis in real-time or in time close to it. Information is processed as it is received and, most importantly, it is aggregated from all levels and sources. Data transmission is performed through cellular networks. BS $g N B$ (Next Generation Node B) provides coverage and wireless data transmission. To communicate with $g N B$ stations, UAVs must be equipped with appropriate transmitters that support $5 \mathrm{G}$ cellular network standards. 


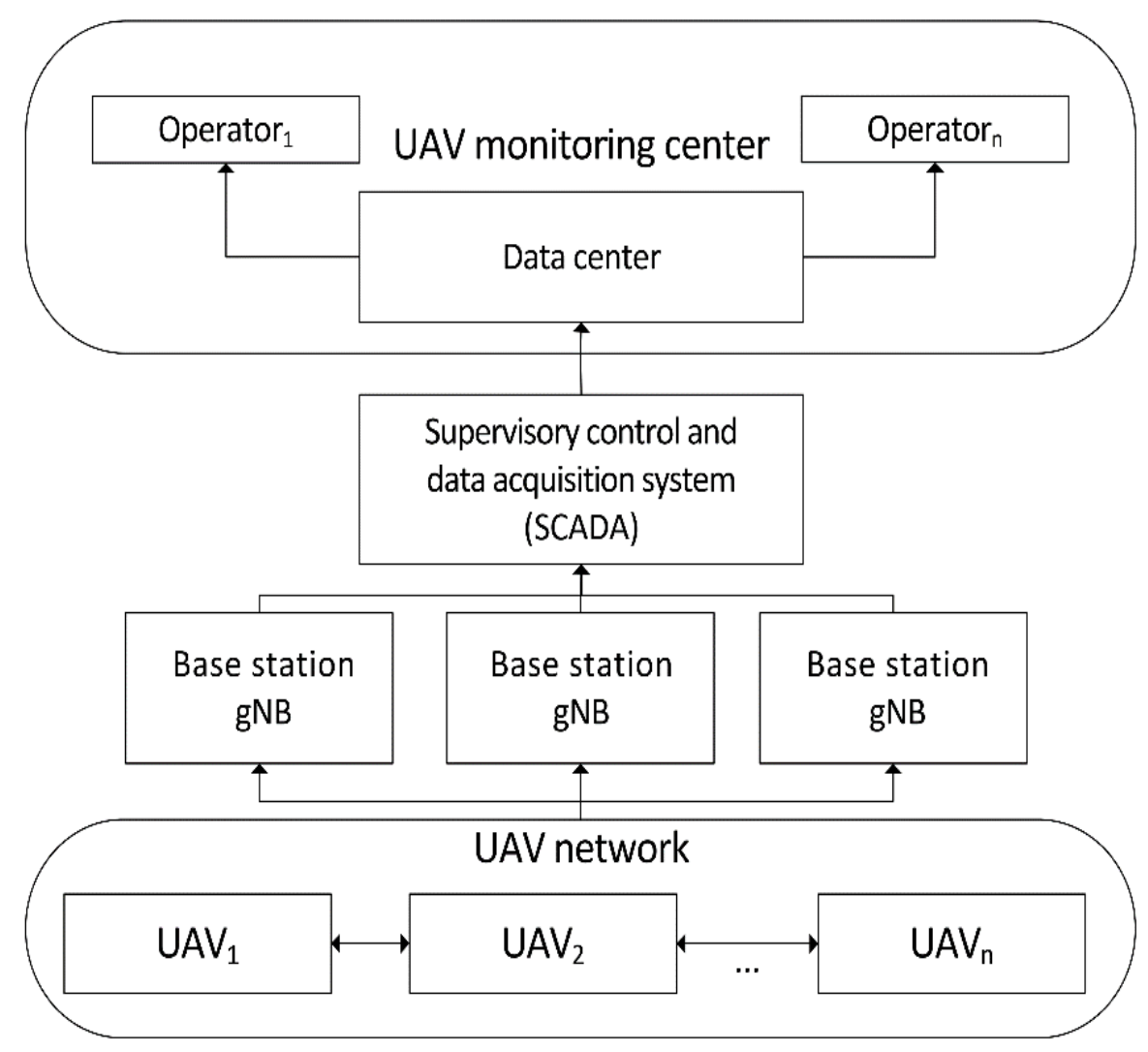

Fig. 2. Implementation scheme of UAVs' monitoring system using cellular networks

The monitoring system analyses UAV's position and detects violations of the airspace, unsafe head-on approaches and other scenarios of aircrafts unauthorized usage. Counteracting to the occurrence and, if possible, liquidation of the infringement consequences includes the continuous monitoring of potentially dangerous locations and objects to take necessary actions towards consequences liquidation; taking necessary actions for fighting with possible violations consequences; fast response on infringements with the help of aircraft; the formation of the possible swift actions, their dispatching, synchronization and maneuvering of resources of the control dynamics $[15,16]$.

The concept of a developed method of monitoring and responding to the infringements in the UAV network is based on the following steps (Fig. 4):

1. An event $E_{1}, \ldots, E_{f}$ of a certain type occurs. It could be an accidental $\left(V_{1}, \ldots, V_{g}\right)$ or purposeful violation $\left(I V_{1}, \ldots, I V_{e}\right)$.

2. Information regarding events are transmitted on specialized allocated BS $g N B$.

3. Base stations compare received information with respective templates, conditions and areas of airspace. Afterwards information regarding purposeful violation $I V_{1}, \ldots, I V_{e}$ is transmitted to SCADA (Fig. 3). 


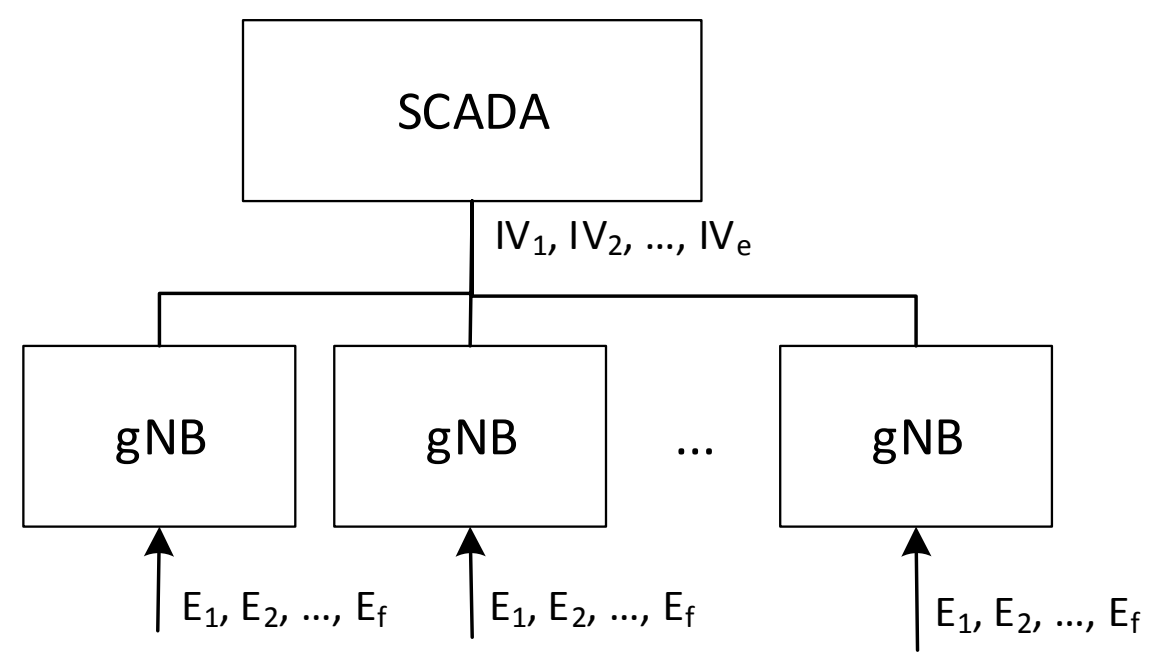

Fig. 3. Transfer of information about events into BS and SCADA

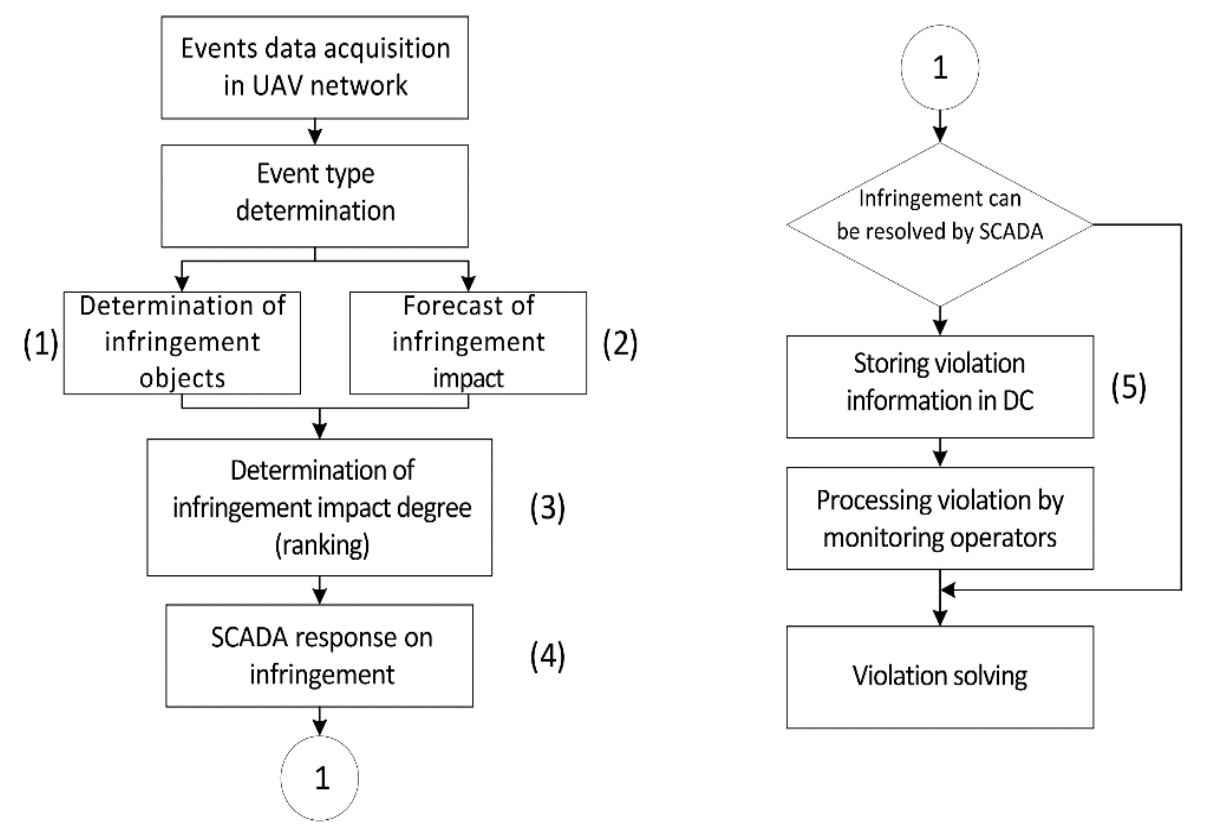

Fig. 4. Algorithm of the proposed monitoring method 
4. Based on a set of rules for responding to the infringement SCADA decides on how it is necessary to react.

5. After processing the violation, SCADA exchanges information with the $\mathrm{UAV}$ monitoring center, where information regarding violation $I V_{1}, \ldots, I V_{e}$ is stored in DC and is given to the monitoring operators.

$g N B$ base stations collect data about every event in the UAV network, caused by both purposeful $I V_{1}, \ldots, I V_{e}$, as well as accidental $I V_{1}, \ldots, I V_{g}$ actions. Infringement premeditation is defined by a comparison of the event parameters with the respective templates.

After this simultaneously the set of objects o, which are possibly affected by the infringement (block 1)

$$
O=\left\{a c=1 a d O_{a c}\right\}=\left\{O_{1}, O_{2}, \ldots O_{a d}\right\},(a c=\overline{1, a d})
$$

is being defined, and the set of extrapolation rules (block 2)

$$
R=\left\{a b=1 a g R_{a b}\right\}=\left\{R_{1}, R_{2}, \ldots R_{a g}\right\},(a b=\overline{1, a g})
$$

is being formed, which allows estimating the potential influence of infringement on airspace objects.

Determination of the influence degree of infringement (block 3) is conducted by the formula:

$$
I L_{b d}=\frac{Q_{b c}}{\sum_{b i=1}^{b c} Q_{b c}}, b i=\overline{1, b c}
$$

where $Q_{b c}$ is the comparative importance coefficient, which is calculated by the formula:

$$
Q_{b c}=\sum_{b i=1}^{b c} a_{b i}, x_{b i b j}, b i=\overline{1, b c}
$$

where $x_{b i b j}$ is the value of $b i$-th criteria of violation type $b j ; a_{b i}$ is the importance of the $b i$-th criteria.

SCADA system response on the infringement is carried out according to the set of rules (block 4)

$$
L=\left\{i=1 n L_{i}\right\}=\left\{L_{1}, L_{2}, \ldots L_{n}\right\} .
$$

In the case when SCADA is capable to positively resolve the violation, it sends the necessary commands back to the violator and stores the respective information in DC. In the other case, when SCADA is unable to resolve the violation, it sends information to DC and monitoring operators. After a successful response to the infringement, its information is stored and the set of such infringements (block 5)

$$
I=\left\{i a=1 n a I_{i a}\right\}=\left\{I_{1}, I_{2}, \ldots I_{n a}\right\}
$$

is formed. 


\section{IMPLEMENTATION AND APPLICATION OF THE SYSTEM}

In the absence of UAV built-in cellular communications, it is necessary to develop a specialized device for the implementation of the proposed system. Such a device must be universal and capable of connecting to any type of UAV. Size variability will be a significant problem when developing a device, but for most models, a universal solution is possible, and mini- and micro-drones will require separate equipment or software reprogramming.

For registration, the buyer must confirm his identity with a passport or other relevant documents. After getting acquainted with the conditions of UAV use and the country's legislation on airspace, the first stage of registration takes place. The second stage occurs during the first activation of the UAV. When buying a UAV in official stores, the seller will be required to register the buyer and create an entry in the register of the Monitoring Center for the purchased device. The record will contain information about the passport data of the buyer and the place of purchase. At the first activation of the UAV, the software and/or hardware of the developed system is started.

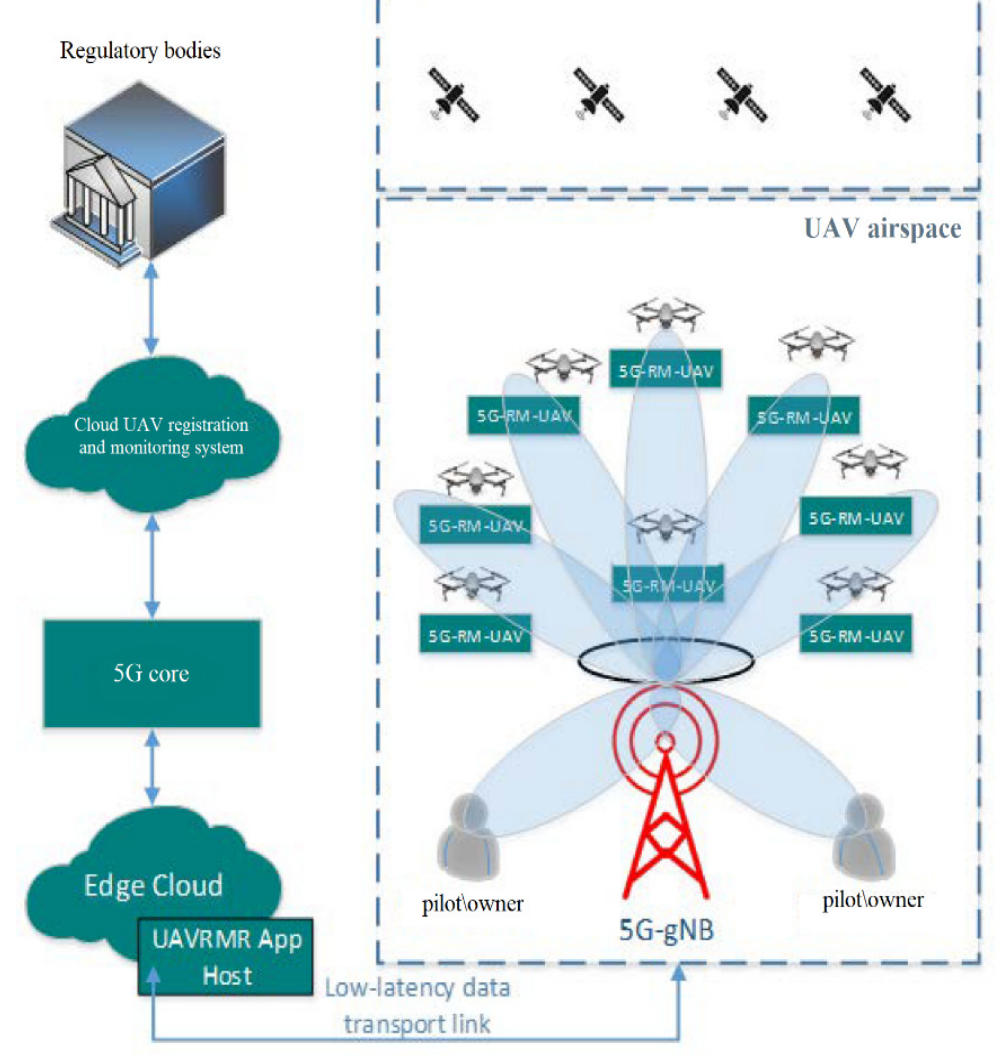

Fig. 5. Implementation of the UAV monitoring and registration center with compliance to the $5 \mathrm{G}$ network architecture 
It sends a signal to the primary server that contains the UAV serial number (IMEI), the date and place of activation, and additional telemetry information. On the server-side, the information for each UAV is combined based on a unique serial number and stored during the operation of the device. If the owner has disconnected the registration and monitoring device himself, he must be held responsible following the adopted legislation.

According to the model of the monitoring system (Fig. 5), the UAV sends the signal to the BS, where it is immediately sent to the local SCADA center, and from there to the UAV monitoring center, where they are analyzed and stored.

The monitoring and recording device sends a signal with a frequency of $5 \mathrm{~s}$, which is a sufficient interval for tracking UAVs during the flight. During the full flight, the device consumes 1000 times less charge than the average battery charge, i.e. the flight time is reduced by $0.1 \%$, which can be neglected. However, much more effective from a software and hardware point of view would be the development of a monitoring and registration system integrated into the onboard equipment of the UAV.

If a violation occurs, the UAV sends a normal signal, which is distinguished as a violation directly in the BS and then, if necessary, is transmitted to the DC for storage. After the detection and registration of the infringement, the aftercoming actions depend on the internal regulations of the country. Among the possible options, there are a fine, a seizure of UAVs, calling of law enforcement officers.

\section{CONCLUSIONS}

The work is devoted to solving the problem of UAV monitoring and registration. The provisions of the documents on unmanned aerial vehicles were considered and it was concluded that in these documents the issue of registration and monitoring is in the initial stages of its solution, there is no clear and unanimous vision of a potential solution to the problem. As shown in the paper, if this problem is not solved, then UAVs can be used for criminal purposes and cause damage to people or property.

Therefore, in order to solve this problem, the possibility of using a new generation of cellular networks to ensure the registration and continuous monitoring of UAVs was considered. As a result, a modern $5 \mathrm{G}$ cellular network was chosen for the development of the communication system. This network has a high data rate with ultra-low latency and is the most advanced of all existing alternatives. The paper also proposed new technology for intelligent control of UAV monitoring, which consists of a monitoring center, a data processing center and the supervisory control and data acquisition system. The use of cellular base stations speeds up the processing of events in the UAV network with the help of filtering. The proposed monitoring system can provide the highest level of safety when using UAVs.

The results of the work can be used by civil aviation regulators to monitor the use of airspace by unmanned aerial vehicles, as well as to prevent casualties and emergencies. 


\section{REFERENCES}

1. Unmanned Aerial Vehicle (UAV) Market - Global Forecast to 2025 MarketsandMarkets, October 2019, p. 322.

2. "Overview of the areas of UAVs' use in everyday life" URL: http://www.50northspatial.org/ ua/uavs-everyday-life/ (Last accessed: 13.10.2020) (in Ukrainian).

3. "Drones and Ukrainian legislation" URL: http://www.50northspatial.org/ua/drony-taukrayinske-zakonodavstvo/ (Last accessed: 13.10.2020) (in Ukrainian).

4. ICAO Cir 328, Unmanned Aircraft Systems (UAS), p. 54 URL: https://www.icao.int/ meetings/uas/documents/circular\%20328_en.pdf. (Last accessed: 13.10.2020)

5. Manual on Remotely Piloted Aircraft Systems (RPAS), ICAO Doc 10019 1st Edition, p. 166 URL: $\quad$ https://store.icao.int/en/manual-on-remotely-piloted-aircraft-systems-rpas-doc-10019. (Last accessed: 13.10.2020)

6. Convention on International Civil Aviation. Ninth Edition. [ebook] Chicago: International Civil Aviation Organization, p. 114 URL: http://www.icao.int/publications/Documents/7300_orig.

7. Zeng, Q. Wu and R. Zhang, "Accessing From the Sky: A Tutorial on UAV Communications for $5 \mathrm{G}$ and Beyond". Proceedings of the IEEE, vol. 107, no. 12, pp. 2327-2375, Dec. 2019

8. A. Fotouhi, H. Qiang, M. Ding, M. Hassan, L. Galati Giordano, A. Garcia-Rodriguez, and J. Yuan "IEEE Survey on UAV Cellular Communications: Practical Aspects, Standardization Advancements, Regulation, and Security Challenges". Journal of communications surveys and tutorials. 2019, pp 1-28

9. M. Mozaffari, W. Saad, M. Bennis, Y.-H. Nam, and M. Debbah. "A Tutorial on UAVs for Wireless Networks: Applications, Challenges, and Open Problems". ArXiv e-prints, Mar 2018 - arXiv:1803.00680

10. S. Hayat, E. Yanmaz, and R. Muzaffar. "Survey on Unmanned Aerial Vehicle Networks for Civil Applications: A Communications Viewpoint". IEEE Communications Surveys Tutorials. 18(4), Fourthquarter 2016, pp.2624-2661.

11. Y. Zeng, R. Zhang, and T. Joon Lim. "Wireless communications with unmanned aerial vehicles: opportunities and challenges". IEEE Communications Magazine. 54(5), 2016, pp. 36-42.

12. NTT DOCOMO Inc., Ericsson. New SID on enhanced support for aerial vehicles. 3GPP RP-170779 RAN\#75, Mar. 2017. URL: https://portal.3gpp.org/ngppapp/CreateTDoc. aspx? mode=view\& contributionUid=RP-170779. (Last accessed: 13.10.2020)

13. 3GPP Technical Document RP 181644. Summary for WI Enhanced LTE Support for Aerial Vehicles. Sept. 2018. URL: https://www.3gpp.org/ftp/TSG_RAN/TSG_RAN/ TSGR_81/Docs/RP-181644.zip. (Last accessed: 13.10.2020)

14. L. Gupta, R. Jain, and G. Vaszkun. "Survey of Important Issues in UAV Communication Networks". IEEE Communications Surveys Tutorials. 18(2) Secondquarter 2016, pp. 1123-1152.

15. Hu Zhengbing, V. Gnatyuk, V. Sydorenko, R. Odarchenko, and S. Gnatyuk. "Method for cyberincidents network-centric monitoring in critical information infrastructure". International Journal of Computer Network and Information Security.9, no. 6, 2017, pp. 30-43

16. R. Odarchenko, P. Usik, O. Volkov, V. Simakhin, O. Gospodarchuk and Y. Burmak "5G Networks Cyberincidents Monitoring System for Drone Communications". 2019 IEEE 5th International Conference Actual Problems of Unmanned Aerial Vehicles Developments (APUAVD) Kyiv, Ukraine, October 22-24, 2019, pp. 165-169.

\section{ЛІТЕРАТУРА}

Received 10.09.2020

1. Unmanned Aerial Vehicle (UAV) Market - Global Forecast to 2025 MarketsandMarkets, October 2019, p. 322

2. “Огляд сфер використання БпЛА в повсякденному житті”. 2016. URL: http://www.50northspatial.org/ua/uavs-everyday-life/ (Дата звернення: 13.10.2020 p). 
3. Дрони та українське законодавство». 2016.2 URL: http:/www.50northspatial.org/ua/drony-ta-ukrayinske-zakonodavstvo/ (Дата звернення: $13.10 .2020 \mathrm{p})$.

4. ICAO Cir 328, Unmanned Aircraft Systems (UAS), p. 54. 2011. URL: https://www.icao.int/meetings/uas/documents/circular\%20328_en.pdf (Дата звернення:13.10.2020 p).

5. Manual on Remotely Piloted Aircraft Systems (RPAS), ICAO Doc 10019 1st Edition, p. 166. 2015. URL: https://store.icao.int/en/ manual-on-remotely-piloted-aircraftsystems-rpas-doc-10019 (Дата звернення 13.10.2020 p).

6. Convention on International Civil Aviation. Ninth Edition. [ebook] Chicago: International Civil Aviation Organization, p. 114 [Електронний ресурс]. - 2006. Режим доступу: http:/www.icao.int/publications/Documents/7300_orig.pdf (дата звернення 13.10.2020 p). - Назва екрану.

7. Zeng, Q. Wu and R. Zhang, "Accessing From the Sky: A Tutorial on UAV Communications for 5G and Beyond". Proceedings of the IEEE, vol. 107, no. 12, pp. 2327-2375, Dec. 2019

8. A. Fotouhi, H. Qiang, M. Ding, M. Hassan, L. Galati Giordano, A. Garcia-Rodriguez, and J. Yuan "IEEE Survey on UAV Cellular Communications: Practical Aspects, Standardization Advancements, Regulation, and Security Challenges". Journal of communications surveys and tutorials 2019, pp 1-28.

9. M. Mozaffari, W. Saad, M. Bennis, Y.-H. Nam, and M. Debbah. "A Tutorial on UAVs for Wireless Networks: Applications, Challenges, and Open Problems”. ArXiv e-prints, Mar 2018 - arXiv:1803.00680

10. S. Hayat, E. Yanmaz, and R. Muzaffar. "Survey on Unmanned Aerial Vehicle Networks for Civil Applications: A Communications Viewpoint”. IEEE Communications Surveys Tutorials, 18(4), Fourthquarter 2016, pp.2624-2661.

11. Y. Zeng, R. Zhang, and T. Joon Lim. "Wireless communications with unmanned aerial vehicles: opportunities and challenges". IEEE Communications Magazine, 54(5), 2016, pp. $36-42$.

12. NTT DOCOMO Inc., Ericsson. New SID on enhanced support for aerial vehicles. 3GPP RP-170779 RAN\#75. 2017. URL: https://portal.3gpp.org/ngppapp/ CreateTDoc.aspx?mode=view\&contributionUid=RP-170779 (Дата звернення 13.10.2020 p).

13. 3GPP Technical Document RP 181644. Summary for WI Enhanced LTE Support for Aerial Vehicles. 2018. URL: https://www.3gpp.org/ftp/TSG_RAN/TSG_RAN/ TSGR_81/Docs/RP-181644.zip (Дата звернення 13.10.2020 p).

14. L. Gupta, R. Jain, and G. Vaszkun. "Survey of Important Issues in UAV Communication Networks". IEEE Communications Surveys Tutorials, 18(2) Secondquarter 2016, pp. 1123-1152.

15. Hu Zhengbing, V. Gnatyuk, V. Sydorenko, R. Odarchenko, and S. Gnatyuk. "Method for cyberincidents network-centric monitoring in critical information infrastructure". International Journal of Computer Network and Information Security 9, no. 6, 2017, pp. $30-43$.

16. R. Odarchenko, P. Usik, O. Volkov, V. Simakhin, O. Gospodarchuk and Y. Burmak "5G Networks Cyberincidents Monitoring System for Drone Communications". 2019 IEEE 5th International Conference Actual Problems of Unmanned Aerial Vehicles Developments (APUAVD) Kyiv, Ukraine, October 22-24, 2019, pp. 165-169.

Отримано 10.09.2020 
Одарченко Р.С., д-р техн. наук, доцент

провід. наук. співроб. відд. інтелектуального управління, e-mail: odarchenko.r.s@ukr.net

ORCID: 0000-0002-7130-1375

Волков О.С.,

зав. відд. інтелектуального управління

e-mail: alexvolk@ukr.net

ORCID: 0000-0002-5418-6723

Сімахін B.M., аспірант,

молодш. наук. співроб. відд. інтелектуального управління

e-mail: thevladsima@gmail.com

ORCID: 0000-0003-4497-0925

Семеног P.B., аспірант,

молодш. наук. співроб. відд. інтелектуального управління

e-mail: ruslansemenog20@gmail.com

ORCID: 0000-0002-6714-0644

Господарчук O.Ю.,

старш. наук. співроб. відд. інтелектуального управління

e-mail: dep185@irtc.org.ua

ORCID: 0000-0001-6619-2277

Міжнародний науково-навчальний центр

інформаційних технологій

та систем НАН та МОН України,

40, пр. Акад. Глушкова, 03187, м. Київ, Україна

\section{ТЕХНОЛОГІЯ 40, ІНТЕЛЕКТУАЛЬНОГО КЕРУВАННЯ МОНІТОРИНГОМ БЕЗПІЛОТНИХ ЛІТАЛЬНИХ АПАРАТІВ У ПОВІТРЯНОМУ ПРОСТОРІ 3 ВИКОРИСТАННЯМ СТІЛЬНИКОВИХ МЕРЕЖ 5G}

Вступ. Зростання кількості безпілотних літальних апаратів (БпЛА) у повітряному просторі, а також недосконалість нормативно-правової бази щодо регулювання їхньої діяльності, ставить численні завдання перед регуляторами. В роботі пропонується розроблення інтелектуальних технологій та програмно-апаратних систем у поєднанні з надсучасними стільниковими мережами 5G для розв'язання завдань реєстрації та моніторингу БпЛА.

Мета статті - проаналізувати стан ринку БпЛА та пов'язаного законодавства у світі та Україні, розробити технологію інтелектуального керування моніторингом БпЛА з використанням стільникових мереж, підготувати вказівки щодо імплементації та застосування системи.

Методи. В роботі використано методи передачі даних у мережах 5G і побудови глобальних розподілених мереж інтернету речей для реалізації технології моніторингу, методи аналізу даних та виявлення аномалій для дослідження подій, що виникають у мережі БпЛА.

Результати. 3 метою розв'язання проблеми моніторингу та реєстрації БпЛА проаналізовано можливість використання стільникових мереж нового покоління для забезпечення реєстрації та безперервного моніторингу БпЛА. Як результат, для розвитку системи зв'язку було вибрано сучасну стільникову мережу 5G, яка є найбільш прогресивною серед усіх сучасних альтернатив.

Розроблено технологію інтелектуального моніторингу БпЛА з використанням сучасної стільникової мережі 5G. Використання мережі п’ятого покоління надає високу швидкість передачі даних з наднизькою затримкою та задовольняе всім необхідним вимогам безпеки. Технологія інтелектуального керування моніторингом БпЛА складається 3 окремих методів, які виконуються в центрі моніторингу, центрі оброблення даних та в системі диспетчерського керування та збору даних. Використання базових станцій стільникових мереж для первинного оброблення та фільтрації даних пришвидшує оброблення подій у мережі БпЛА. 
Висновки. Використання базових станцій стільникових мереж пришвидшує оброблення подій у мережі БпЛА шляхом фільтрації. Запропонована система моніторингу може забезпечити найвищий рівень безпеки у разі використання БпЛА.

Результати роботи можуть бути використані регуляторними органами у галузі цивільної авіації з метою контролю за використанням повітряного простору безпілотними апаратами, а також для запобігання виникненню нештатних та аварійних ситуацій.

Ключові слова: інформаційна технологія, система моніторингу, система реєстрації, безпілотний літальний апарат, мережа $5 G$. 